\title{
Verification of the seismic P-wave velocities under Moho boundary: Central Poland case study, LUMP profile
}

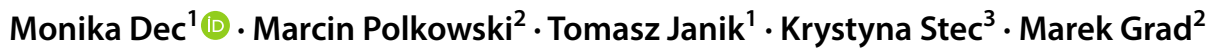

Received: 25 October 2017 / Accepted: 6 December 2018 / Published online: 13 December 2018

(c) The Author(s) 2018

\begin{abstract}
The tectonic settings investigated by several seismic projects in previous research targeting the structure in Central Poland mainly focused on the Earth's crust. In this paper, we present P-wave velocity verification in the uppermost mantle beneath LUMP profile towards SSE-NNW. Using recordings of 36 DATA-CUBE recorders from ca. 300-490 km far earthquake in coal mine "Janina" in southern Poland, we calculated travel times to verify P-wave velocity below the Moho boundary from previous studies. It shows that a significantly lower mean velocity value should be used for the upper mantle while counting these offsets of travel times in the SSE-NNW direction than that used on previous profiles. We present two possible models: first, the most simple one that fits the observed first arrivals, and the second with a low-velocity layer beneath the Moho boundary. In both cases, we used a priori crustal model focusing only on P-wave velocity in the uppermost mantle. Both of them significantly improved adjustment of travel times to the observed data. To evaluate the tendency of adopting too high velocities beneath the Moho, we used also 11 broadband stations, Reftek 151-121 "Observer", from "13 BB Star" passive experiment and 6 STS-2 seismometers from permanent stations of the Polish Seismological Network (PLSN).
\end{abstract}

Keywords Upper mantle structure $\cdot$ Central Poland $\cdot$ P-wave velocity $\cdot$ Seismic profile

\section{Introduction}

The tectonic structure in Poland, where the East European Craton and Palaeozoic Platform are divided by the TransEuropean Suture Zone, is complicated (Fig. 1). The cross sections were modelled along relatively dense net of the seismic profiles in several projects, as, for example, POLONAISE'97 (e.g. Guterch et al. 1997), CELEBRATION 2000 (e.g. Guterch et al. 2003) or SUDETES 2003 (e.g. Grad et al. 2003). Figure 2 presents some of these profiles. The 2D models along particular profiles were the basis for creating 3D models by Majdański (2012) and Grad et al. (2016). These profiles were acquired during active source seismic experiments, where recorded energy is significantly lower than in case of natural earthquakes.

Monika Dec

monikadec@igf.edu.pl

1 Institute of Geophysics, Polish Academy of Sciences, Warsaw, Poland

2 Faculty of Physics, Institute of Geophysics, University of Warsaw, Warsaw, Poland

3 Central Mining Institute, Katowice, Poland
In 2015, there was an earthquake in the coal mine close to Libiąż town. At that time, we had a profile set up to record the energy from the detonation of one old sea mine with a total charge ca. $1700 \mathrm{~kg}$ of TNT from the FENNOLORA (1979) project (Lund et al. 1983). After almost 40 years since the FENNOLORA seismic experiment, the last unexploded military charge was detonated. All countries bordering the Baltic Sea were informed and set up their own equipment. Throughout the Scandinavian Peninsula, the energy from this blast was recorded (Lund 2015). Unfortunately, on the southern part of the Baltic Sea the energy from that blast was poorly recorded, probably because of the very bad weather conditions-strong wind and storm generating too much noise.

Deployment of stations at that time allowed us to record the mining event close to Libiąż town. The distance between the source and the receivers made it possible to verify P-wave velocity in the uppermost mantle in Central Poland. Assuming well-investigated crustal structures, we present an attempt to examine P-wave distribution below the Moho boundary or discontinuity based on Libiąż Uppermost Mantle Profile (LUMP profile). We used also recordings of all seismic stations deployed in Poland at that time (see Table 1). 


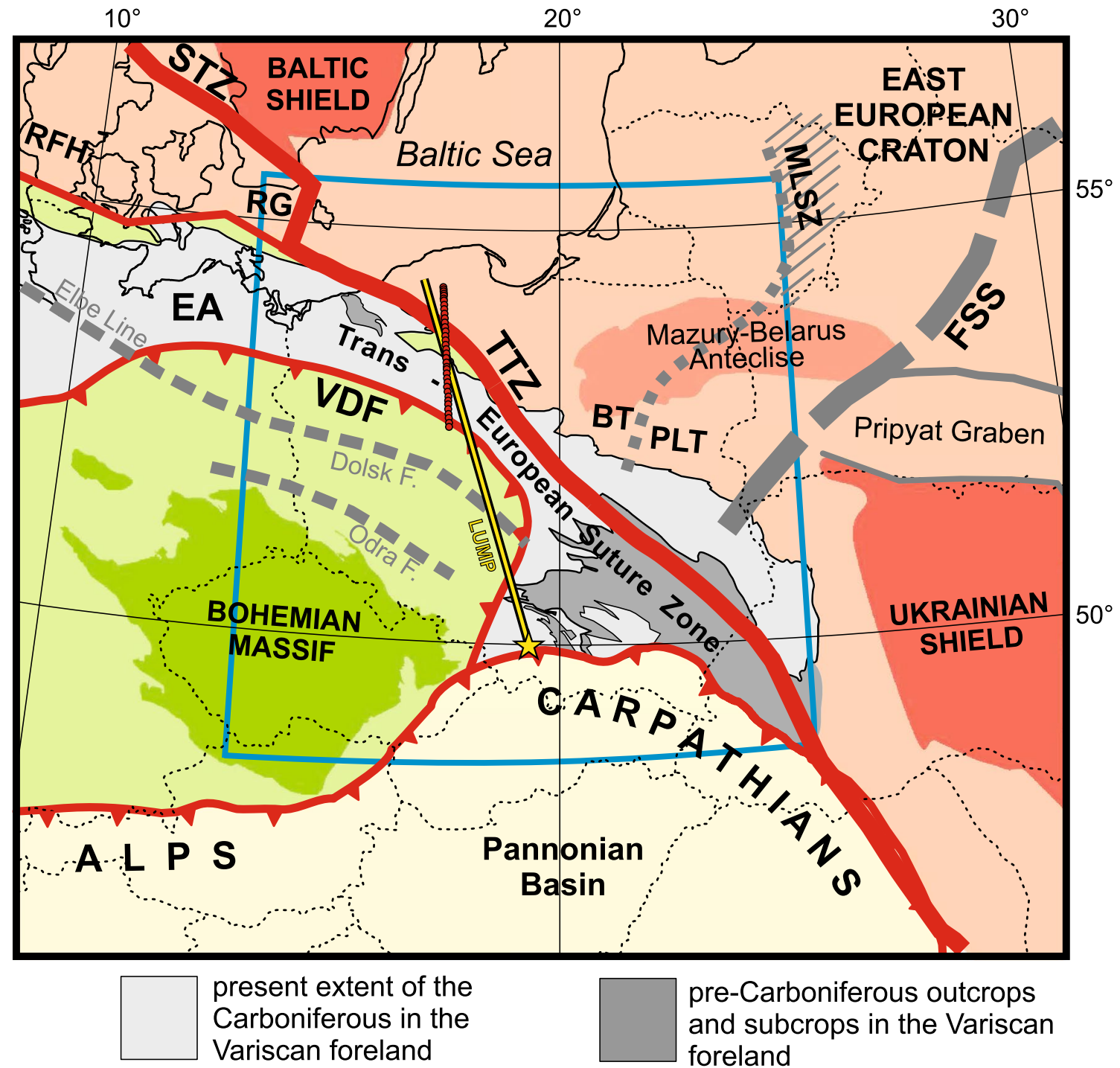

Fig. 1 Tectonic sketch of the pre-Permian Central Europe in the contact of the East European Craton, Variscan and Alpine orogens compiled mainly from Pożaryski and Dembowski (1983), Ziegler (1990), Winchester et al. (2002), Skridlaitè et al. (2006), Cymerman (2007), Narkiewicz et al. (2011), Franke (2014) and Mazur et al. (2015). Blue frame shows the location of studied area. BT Baltic Terrane, EA Eastern Avalonia, FSS Fennoscandia-Sarmatia Suture, MLSZ Mid-Lithuanian Suture Zone, PLT Polish-Latvian Terrane, $R G$ Rønne Graben,

First, we present data-seismic waveforms from Libiąż seismic event. Second, we describe the methods used in this analysis (2D ray-tracing modelling). The modelling and results section presents two new models of the analysed region with seismic sections together with the travel times calculated for our models. Finally, we discuss the results.
RFH Ringkobing-Fyn High, STZ Sorgenfrei-Tornquist Zone, TTZ Teisseyre-Tornquist Zone, $V D F$ Variscan Deformation Front. The area of Bohemian Massif is highlighted in dark green. The TransEuropean Suture Zone separates thick and cold Precambrian crust from younger thin and hot Paleozoic crust. Yellow star shows the location of Libiąż earthquake which was recorded at LUMP seismic stations (red dots). Yellow line shows the LUMP profile

\section{Tectonic settings}

The LUMP profile line intersects three main tectonic units: the East European Craton in the north, Palaeozoic Plate in the south and the Trans-European Suture Zone that separates them (see Fig. 1). 


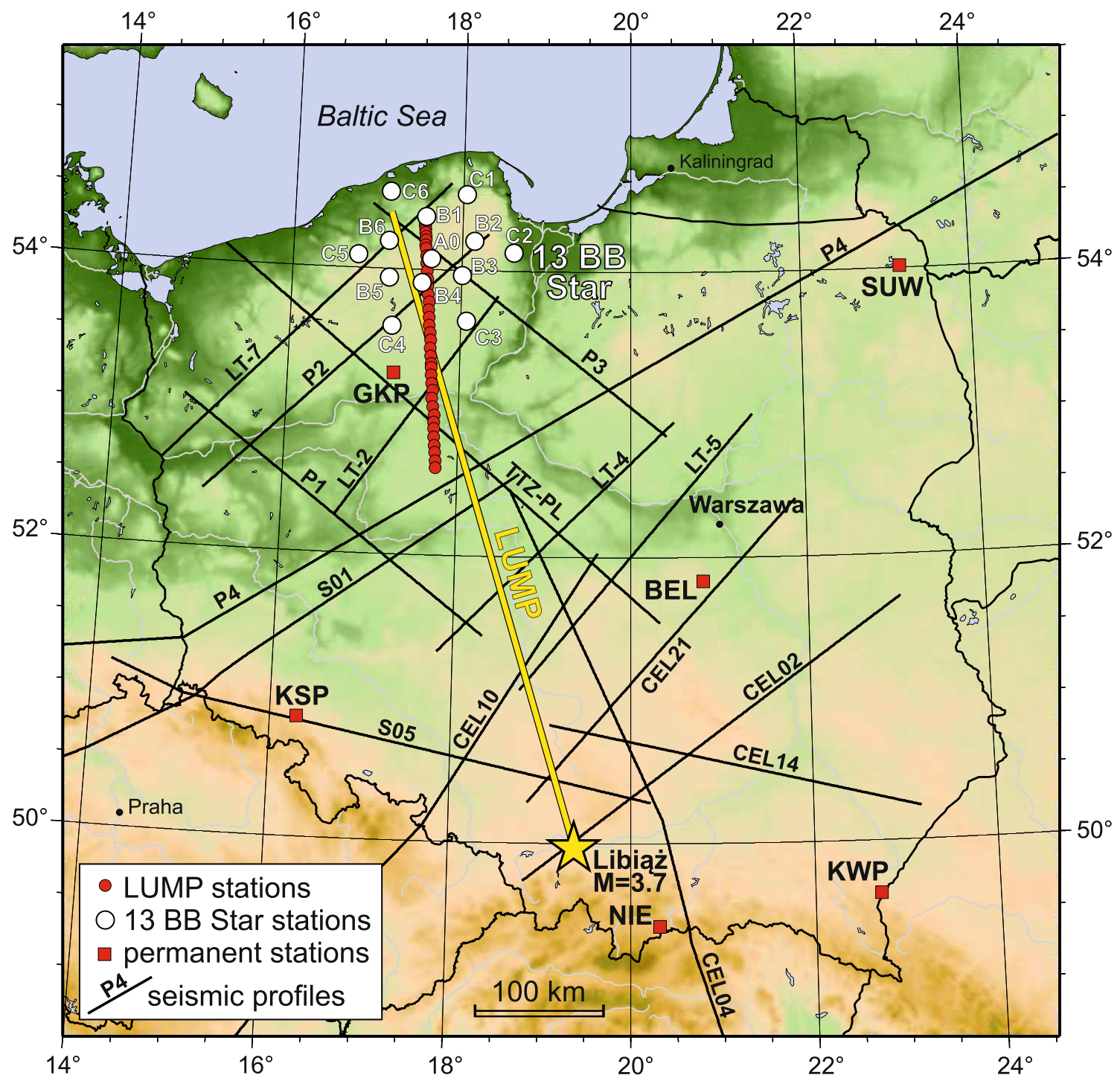

Fig. 2 The net of selected profiles from the region neighbouring the LUMP profile on the background of the topographic map. Yellow star shows location of Libiąż earthquake which was recorded at LUMP seismic stations (red dots). "13 BB Star" array of broadband sta-

The East European Craton (EEC) is the oldest part of Europe. It was formed around 1.8-1.7 billion years ago, due to the collision of three independent segments: Fennoscandia, Sarmatia and Volgo-Uralia (Bogdanova et al. 2001, 2005). There are metamorphic rocks of Archaean and Proterozoic age in the Precambrian platform, including plutonic and volcanic rocks, both alkaline and acidic. These are mainly migmatites, gneisses, amphibolites, granitic rocks and igneous rocks such as gabbros, syenites, granitoids, norites with a thick sediment coverage $\sim 5 \mathrm{~km}$ on the $\mathrm{SW}$ rim, which gradually reduces its thickness towards the NE direction (Bogdanova et al. 2006; Puziewicz 2006; Puziewicz et al. 2017). tions is denoted with white dots and permanent seismic stations with red squares, respectively. Yellow line shows the LUMP profile. Thin black lines are profiles used for the construction of the Model Z

The Trans-European Suture Zone (TESZ) separates the young Paleozoic structures of Central and Western Europe from the old Precambrian structures of northern and eastern parts. This area was created as a result of the collisions of Baltica, Laurentia, Gondwana and Avalonia (Gee and Zeyen 1996). The western margin of East European Craton is the most prominent lithospheric border in Europe. It runs from north-west to south-east, from the North Sea to the Black Sea, at a length of about $2000 \mathrm{~km}$. This zone of the Palaeozoic collision of the Precambrian East European Craton with the micro-continents of Avalonia, Barrandian and Armorica (which broke off from Gondwana in the south) is almost hidden in deep sedimentary basins from the Permian to the 
Table 1 List of seismic broadband stations

\begin{tabular}{llllll}
\hline No. & Name & Lat $\left({ }^{\circ} \mathrm{N}\right)$ & Lon $\left({ }^{\circ} \mathrm{E}\right)$ & Elevation $(\mathrm{m})$ & $\begin{array}{l}\text { Distance from } \\
\text { Libiąż event } \\
(\mathrm{km})\end{array}$ \\
\hline 1 & & & & & 406.9 \\
2 & B3 & 53.64291 & 18.06823 & 121 & 442.6 \\
3 & B4 & 53.96410 & 18.00966 & 138 & 444.2 \\
4 & B5 & 53.93703 & 17.14901 & 158 & 455.6 \\
5 & A0 & 54.07505 & 17.63717 & 165 & 460.4 \\
6 & B2 & 54.20622 & 18.14512 & 259 & 467.2 \\
7 & C5 & 54.11620 & 16.77978 & 119 & 482.9 \\
8 & B6 & 54.19633 & 17.13096 & 90 & 483.2 \\
9 & B1 & 54.37191 & 17.56642 & 120 & 493.6 \\
10 & C1 & 54.53468 & 18.04281 & 154 & 504.4 \\
11 & C6 & 54.53999 & 17.13336 & 61 & 519.4 \\
12 & NIE & 49.4189 & 20.3131 & 649 & 101.0 \\
13 & BEL & 51.8355 & 20.7888 & 173 & 221.1 \\
14 & KSP & 50.8428 & 16.2931 & 353 & 232.7 \\
15 & KWP & 49.6314 & 22.7075 & 448 & 247.1 \\
16 & GKP & 53.2697 & 17.2367 & 115 & 384.4 \\
17 & SUW & 54.0125 & 23.1808 & 152 & 511.4 \\
\hline
\end{tabular}

Numbers from column 1 correspond to numbers of stations in Fig. 6. Stations are sorted according to increasing distance: 1-11, stations from 13 BB Star experiment, and 12-17, permanent PLSN stations. For their locations, see also Fig. 2
Cenozoic age. In the studies of the history of this region, many seismic experiments and drilling holes are helpful. This border is also present in the upper mantle (e.g. Babuška et al. 1998; Wilde-Piórko et al. 2010).

\section{Previous seismic studies}

Geophysical research in this area consists mainly of seismic methods. Numerous profiles (Fig. 2, Table 2) were recorded in both the eastern and western parts of TESZ (e.g. Guterch et al. 2010). Seismic projects, such as the LT profiles in Poland (Guterch et al. 1986), TTZ-PL (Grad et al. 1999), POLONAISE'97 (Guterch et al. 1999), CELEBRATION 2000 (Guterch et al. 2003) and SUDETES 2003 (Grad et al. 2003), provided information on crustal structure for the East European Craton and neighbouring areas. These projects provided a large number of crustal structure images down to the Moho boundary, but only in a few cases there were deeper interpretations (Grad et al. 2002). During deep seismic soundings, some upper mantle phases, both reflected and refracted, were traced on up to distances of $400 \mathrm{~km}$ (POLONAISE'97, Grad et al. 2002).

In 1997, the POLONAISE'97 project (Polish Lithosphere Onsets-An International Seismic Experiment) was

Table 2 Seismic profiles crossing LUMP profile and in its vicinity, sorted from the north to south

\begin{tabular}{|c|c|c|c|c|c|}
\hline Name of the profile & Year & $\begin{array}{l}\text { Length of the } \\
\text { profile }(\mathrm{km})\end{array}$ & Experiment & $\begin{array}{l}\text { Crossing distance at } \\
\text { LUMP profile }(\mathrm{km})\end{array}$ & References \\
\hline $\mathrm{P} 3$ & 1997 & 300 & POLONAISE’97 & 503 & $\begin{array}{l}\text { Środa and POLONAISE Working Group } \\
\text { (1999) }\end{array}$ \\
\hline LT-7 & 1987 and 1992 & 560 & LT-7 & 492 & Guterch et al. (1994) \\
\hline $\mathrm{P} 2$ & 1997 & 300 & POLONAISE’97 & 434 & Janik et al. (2002) \\
\hline LT-2 & 1974 & 220 & LT-2 & 370 & Guterch et al. (1986), Grad et al. (2005) \\
\hline TTZ-CEL03 & 1993 and 2000 & 740 & $\begin{array}{l}\text { TTZ-PL and CEL- } \\
\text { EBRATION } 2000\end{array}$ & 317 & Grad et al. (1999), Janik et al. (2005) \\
\hline $\mathrm{P} 4$ & 1997 & 800 & POLONAISE'97 & 294 & Grad et al. (2003) \\
\hline S01 & 2003 & 630 & SUDETES 2003 & 264 & Grad et al. (2008) \\
\hline LT-4 & 1977 & 255 & LT-4 & 200 & Guterch et al. (1986), Grad et al. (2005) \\
\hline CEL10 & 2000 & 720 & CELEBRATION 2000 & 136 & $\begin{array}{l}\text { Hrubcova et al. (2008), Grad et al. (2009a), } \\
\text { Janik, not published }\end{array}$ \\
\hline LT-5 & 1979 & 300 & LT-5 & 125 & Guterch et al. (1986), Grad et al. (2005) \\
\hline CEL14 & 2000 & 300 & CELEBRATION 2000 & 91 & Środa et al. (2006) \\
\hline CEL21 & 2000 & 320 & CELEBRATION 2000 & 49 & Janik et al. (2009) \\
\hline S05 & 2003 & 440 & SUDETES 2003 & 38 & Janik, model under preparation \\
\hline CEL02 & 2000 & 400 & CELEBRATION 2000 & 9 & Malinowski et al. (2005) \\
\hline CEL04 & 2000 & 630 & CELEBRATION 2000 & Parallel & Środa et al. (2006) \\
\hline $\mathrm{P} 1$ & 1997 & 300 & POLONAISE'97 & Parallel & Jensen et al. (1999) \\
\hline
\end{tabular}


conducted, aiming to study the lithosphere structure within the TESZ and the south-western part of the East European Craton (Guterch et al. 1999). Profile P4, which had its origin in SE Germany, passed through Poland and ended in Lithuania, was the longest POLONAISE'97 profile. Its length was about $900 \mathrm{~km}$. Modelling of this area shows a visible change in the depth of the Moho from $30 \mathrm{~km}$ on the Palaeozoic platform to $\sim 45 \mathrm{~km}$ under the TESZ and $40-50 \mathrm{~km}$ below the East European Craton.

Another project on a similar scale was CELEBRATION 2000 (Central European Lithospheric Experiment Based on Refraction). The total length of the profiles was $8900 \mathrm{~km}$, with 147 shots (Guterch et al. 2003). The longest profile $(1400 \mathrm{~km})$ CEL05 crossed tectonic units of the EEC, the TESZ, the Carpathians and the Pannonian Basin. Modelling of this profile was initially based on the inversion of first arrivals only (Guterch et al. 2003), but later ray tracing was used (Grad et al. 2006). In the area of the EEC, a three-layer crustal structure was established. The CEL03 profile was a prolongation of previous TTZ-PL profile, jointly $\sim 720 \mathrm{~km}$ long. The profiles run along the TESZ. Analysis of this profile has shown that the TESZ is not homogeneous. Several smaller units were separated within it (Janik et al. 2005). The depth of the Moho boundary varies from $\sim 30 \mathrm{~km}$ in the Baltic Sea to $\sim 50 \mathrm{~km}$ at the Ukrainian border.

In 2006-2008, the PASSEQ project was conducted, which provided further important data for detailed investigation of the upper mantle structure around the TESZ region in Central Europe (Wilde-Piórko et al. 2008). One of its results is a model of P-wave velocity variations with $\pm 3 \%$ in relation to the iasp 91 velocity model around the TESZ (Janutyte et al. 2015). Using the TELINV nonlinear teleseismic tomography algorithm to perform the inversions, the seismic lithosphere-asthenosphere boundary (LAB) was found to be more distinct beneath the Phanerozoic part of Europe than beneath the Precambrian part.

The TESZ area was investigated previously in projects such as EUGENO-S (e.g. EUGENO-S Working Group 1988), EGT (European Geotraverse; e.g. Blundell et al. 1992) and BABEL (Baltic and Bothnian Echoes from the Lithosphere; BABEL Working Group 1993). Recent years show great interest in this area. Projects such as POLONAISE'97, CELEBRATION 2000 and SUDETES 2003 provided 2D and 3D models of seismic wave velocity based on deep seismic probes. These models illustrate the crust structure in the TESZ region, but the depth range of the models does not allow for precise determination of the upper mantle structures.

The crustal structure of the EEC is characterized by a thin sedimentary cover, of up to $2 \mathrm{~km}$, and consists of three layers. The top crystalline layer has seismic P-wave velocities of $6.0-6.4 \mathrm{~km} / \mathrm{s}$, mid-layer of $6.5-6.8 \mathrm{~km} / \mathrm{s}$ and lower layer of $6.8-7.2 \mathrm{~km} / \mathrm{s}$. The Moho boundary lies here at a depth of 43-50 km (Grad et al. 2006). Towards the TESZ, the seismic structure is composed of a sedimentary layer of 9-12 km with P-waves of less than $5.4 \mathrm{~km} / \mathrm{s}$. Beneath, there is a consolidated upper crust (basement) at a depth of $15-20 \mathrm{~km}$ with P-wave velocity less than $6 \mathrm{~km} / \mathrm{s}$, middle crust with velocities of $6.3-6.6 \mathrm{~km} / \mathrm{s}$ and lower crust with $\mathrm{Vp}$ values of $6.8-7.2 \mathrm{~km} / \mathrm{s}$.

The results of deep seismic surveys show how complex the structure of the Earth's crust is in this area. These soundings also point out differences in physical characteristics, which correspond to their differences in geological structure. Analysis of the results of these projects allowed, for example, to designate the Moho depth map (e.g. Grad et al. 2009b).

\section{Seismic data and Libiąż event}

In this analysis, we used 36 short-period DATA-CUBE recorders, 11 broadband stations, Reftek 151-121 "Observer", from "13 BB Star" passive experiment (Grad et al. 2015) and 6 from permanent broadband stations of the Polish Seismological Network (PLSN) equipped with STS-2 seismometers (locations in Table 1). Map of the LUMP seismic profile (yellow line) with all stations is shown in Fig. 2. DATA-CUBE recorders with $4.5 \mathrm{~Hz}$ geophones were deployed for 1 week only.

We used the source location catalogue with data calculated from mining seismometers (http://www.grss.gig.eu/ pl), according to which the event occurred in $50.0717 \mathrm{~N}$, $19.3396 \mathrm{E}$ at the $1 \mathrm{~km}$ depth.

Seismic section composed of short-period data is presented in Fig. 3. Stations along the LUMP profile were deployed from $52.61220 \mathrm{~N}, 17.74969 \mathrm{E}$ to $54.31169 \mathrm{~N}$, $17.54922 \mathrm{E}$ with average spacing $5.3 \mathrm{~km}$. At $300-490 \mathrm{~km}$ offsets, we observed uppermost mantle seismic waves. The largest amplitudes are observed for first P-wave arrivals. We notice strong crustal P-wave multiples, but due to the complicated structure above the Moho discontinuity, attributing them to individual layers in the crust could be difficult. We recorded data on one-component DATA-CUBE with 100 cps, and on vertical component, we do not observe significant first-mantle S-waves. Trying to establish their position in Fig. 3, we mark a grey zone for approximately $\mathrm{Vp} /$ Vs $\sim 1.73$ for both S-waves and crustal S-waves multiples.

To describe the source and energy radiation, we present moment tensor solution (Fig. 4). The "Janina" mine is located in Main Trough, the most extensive structure of Upper Silesian Coal Basin (USCB) (Buła et al. 2008; Bukowska 2012). It is a very gentle and extensive syncline with layer dip from $0^{\circ}$ to $10^{\circ}$. Its main structural elements include a number of faults of varying amplitude of throws, often above $1000 \mathrm{~m}$, and mild bending of layers in the form of domes, anticlinal faults or troughs and synclines. The 
Fig. 3 Seismic section recorded in northern Poland by LUMP stations (see Fig. 2 for location). Normalized Z-component, filtration $0.5-9.0 \mathrm{~Hz}$

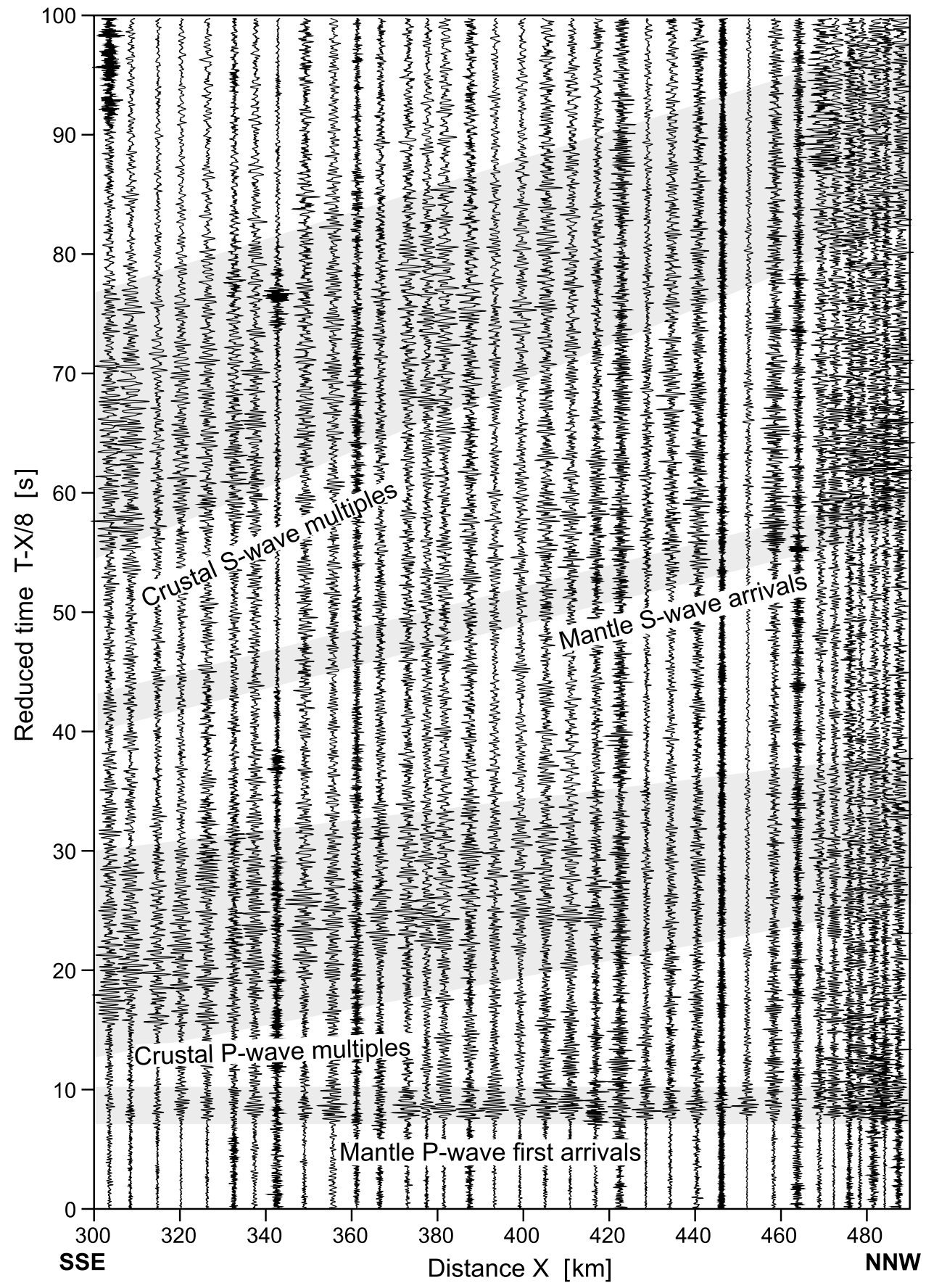

faults are mostly of regular throw and throw-slip kind, rarely only slip. The length of fault zones is not equal and ranges from a few metres to several dozen kilometres. Similarly, the orientation of faults varies from the latitudinal faults to the meridian; the latitudinal faults are characterized also by substantial throws, accumulated mainly in the central and southern part of the trough. Due to the fact that they throw rock mass to the south, the structure of the throw is stepwise, whereas the meridional faults are located almost all over the area, and the NW-SE faults could be found only along the $\mathrm{NE}$ and $\mathrm{E}$ border.

The strong seismic event of $M_{\mathrm{L}}=3.7$ occurred on November 11, 2015, during the coal seam 207 exploitation in "Janina" mine in Libiąż, southern Poland. In Fig. 4 we present the source mechanism of Libiąż seismic event which was determined from records of 11 channels of local "Janina" mine network. They were in the distance range of $300-490 \mathrm{~m}$ from the source and covered the azimuthal range quite well. In Fig. 4 they are projected into the focal sphere, 


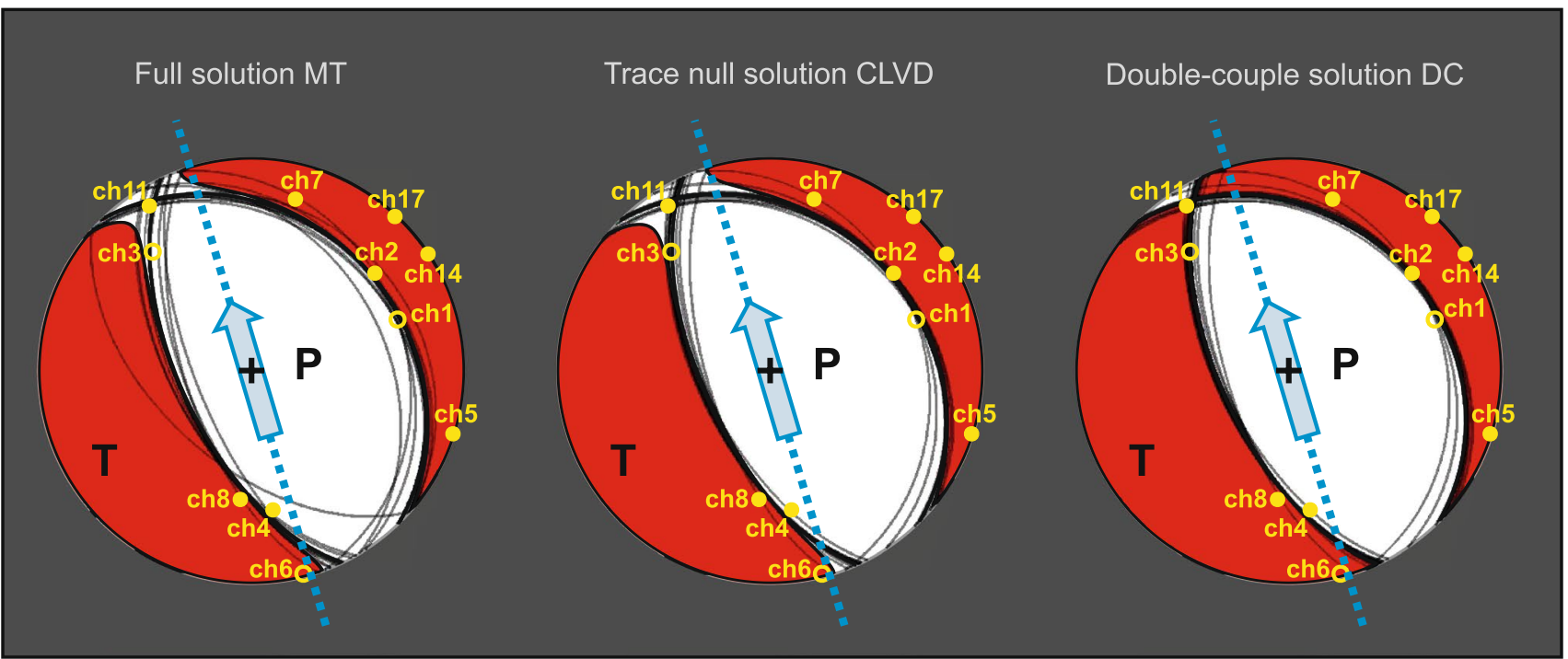

Fig. 4 Source mechanism of Libiąż seismic event with a location of 11 channels of the local seismic network ("Janina" mine) used for moment tensor solution. They are at a distance of 310-1500 m from the source and cover the azimuthal range quite well. In this figure, their locations are projected into the focal sphere. The blue arrows show the direction to central stations at the LUMP profile (azimuth $343^{\circ}$ ). For this direction, mostly P-wave energy is generated, while the $\mathrm{S}$-wave energy is much smaller which explains weak $\mathrm{S}$-waves

and the blue arrows show the direction to central station of the LUMP profile.

For the analysed seismic event, the focal mechanism was calculated with seismic moment tensor inversion method (SMT) in the time domain from amplitudes and polarity of P-wave (Fig. 4). The SMT analysis was based on the seismograms recorded by underground seismic network in "Janina" mine. At the time of the event occurrence, the seismic network consisted of nine vertical and three three-component short-period (1-200 Hz) DLM3D seismometers manufactured by Central Mining Institute, with sampling rate of 500 cps. The recording seismometers are horizontally and vertically spaced from the seismic events at distance ranges of $0.4-3 \mathrm{~km}$ and $0.1-0.8 \mathrm{~km}$, respectively.

The inversion was performed using FOCI 3.1.24 software (Kwiatek et al. 2016), applying constant velocity and density of $4.00 \mathrm{~km} / \mathrm{s}$ and $2300 \mathrm{~kg} / \mathrm{m}^{3}$, respectively. As a result of the calculations, three solutions were obtained following the convention introduced by Knopoff and Randall (1970):

- The full moment tensor, which can be decomposed into an isotropic component (ISO) describing the volume change, linear vector dipole (CLVD) and into the doublecouple component (DC).

- The deviatoric tensor, containing a CLVD component and the shear component DC. recorded at profile. a Full solution MT. The full moment tensor, which can be decomposed into an isotropic component (ISO) describing the volume change, linear vector dipole (CLVD) and into the double-couple component (DC) corresponding to the shear motion. b Trace null solution CLVD. The deviatoric tensor having a CLVD component and the shear component DC. c Double-couple solution (DC). The pure shear tensor, which has only the double-couple component (DC)

- The pure shear tensor, which has only the double-couple component (DC).

Figure 4 shows the parameters of the focal mechanism. The full, deviatoric and pure shear moment tensor was calculated using the L2 norm which was a measure of the misfit together with the Lagrange multipliers method (Wiejacz 1991).

The full moment tensor solution presented in Fig. 4 shows that the earthquake occurred as normal faulting on a northwest-striking plane. It is consistent with approximate strike local fault. Nodal plane A (trend $-155^{\circ}$, dip $-63^{\circ}$ ) is almost vertical and plane $\mathrm{B}$ (trend $-316^{\circ}$, dip $-27^{\circ}$ ) almost horizontal. High double-couple component of the moment tensor solution, which in here is almost $95 \%$, confirmed that the probable cause was the effect of tectonic zones disturbed by mining activity.

\section{Modelling and results}

\section{First check of data with 3D model}

To compute seismic travel times with 3D seismic velocity model of Poland, the "pySeismicFMM" software package was used. The "pySeismicFMM" is Python-based travel 
time calculation software in regular 2D and 3D grids in geographic and Cartesian coordinates. For given geographic coordinates of seismic source within the model, "pySeismicFMM" calculates travel times to all grid cells of the model in single pass, providing accurate travel time to any geographic coordinate within the model. The program uses the fast marching method (Sethian 1996; Sethian and Popovici 1999).

The 3D P-wave velocity model Grad et al. (2016) was obtained by combining data from studies from past 50 years and used data sources such as refraction and reflection seismology, vertical seismic profiling, geological boreholes, magnetotellurics and gravimetry. Such numerous data sources allowed to create detailed 3D P-wave velocity model which reaches to a depth of $60 \mathrm{~km}$. It includes six layers of sediments, three layers of the crust and a single layer of uppermost mantle. The model grid covers a whole area of Poland from topography to $60 \mathrm{~km}$ depth. This model was calculated in a rectangular grid in geographic coordinates.
Each grid cell is assigned to one of the layers. A single grid cell has size of $1112 \mathrm{~m} \times 1281 \mathrm{~m} \times 10 \mathrm{~m}$ for northern Poland and $1112 \mathrm{~m} \times 1459 \mathrm{~m} \times 10 \mathrm{~m}$ for southern Poland. More detailed information can be found in Grad et al. (2016).

We used this model as a starting model in our study. In Fig. 5a we present the vertical cross section obtained from this 3D model between Libiąż location and the middle point of the LUMP profile. Seismic sections (Fig. 5b) with travel times calculated for the 3D model show that the fit to the data should be improved. The root mean square (RMS) value for this model is $0.924 \mathrm{~s}$ with picking accuracy $0.1 \mathrm{~s}$. All source-receiver seismic rays penetrate the uppermost mantle. Tracing wave propagation, we notice that due to the distance, only the part of the model beneath the Moho could be slightly corrected.

Although P-wave penetration is not deep enough (down to $\sim 10 \mathrm{~km}$ below the Moho) to evaluate seismic velocities, we noticed that uppermost values are too high. Propagation of $\mathrm{P}$ below the Moho begins at a relatively high velocity,

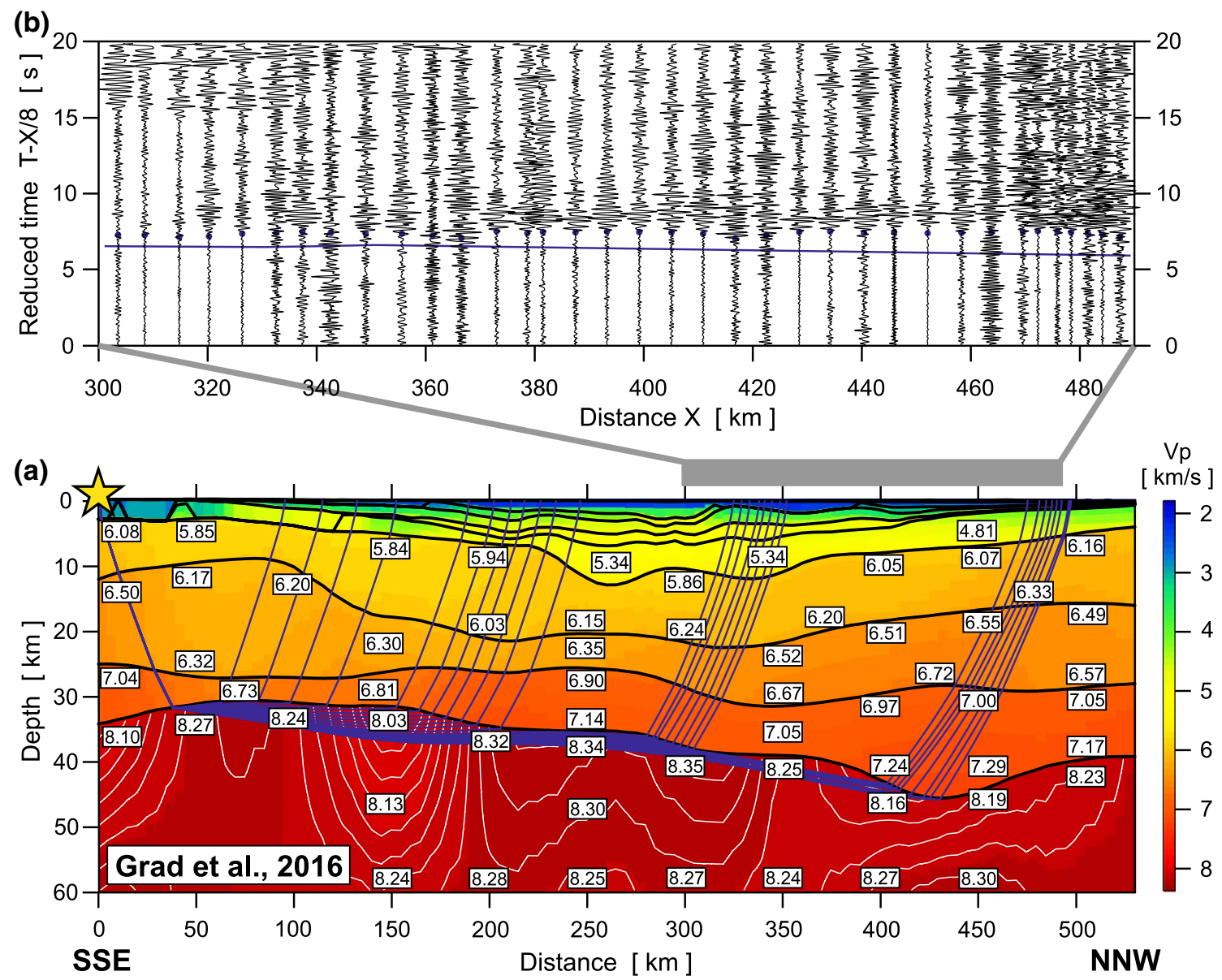

Fig. 5 aVertical cross section obtained from 3D model of P-wave velocity in Poland (Grad et al. 2016) between the event location and middle point of the LUMP profile. Thick, black lines represent velocity discontinuities (interfaces). Velocity values in $\mathrm{km} / \mathrm{s}$ are shown in white boxes. Thin, white lines represent velocity contour lines (each $0.03 \mathrm{~km} / \mathrm{s}$ ). Blue lines correspond to ray paths. b Seismic sections with travel times calculated for the 3D model (blue line). Normalized Z-component, filtration 1.5-6.0 Hz. Blue dots represent first arrivals 
with $\sim 8.27 \mathrm{~km} / \mathrm{s}$ at $\sim 50 \mathrm{~km}$ distance. This value decreases down to $\sim 8.03 \mathrm{~km} / \mathrm{s}$ at distance $\sim 150 \mathrm{~km}$. In the middle of the LUMP, there are high $\mathrm{P}$ velocities at distances from 190 to $350 \mathrm{~km}$ with $\sim 8.34 \mathrm{~km} / \mathrm{s}$ at $250 \mathrm{~km}$ and $\sim 8.36 \mathrm{~km} / \mathrm{s}$ at $300 \mathrm{~km}$. This "island" with high velocities is characterized by negative gradient of $\mathrm{P}$ velocities. Further along the profile, at a distance above $350 \mathrm{~km}, \mathrm{P}$ velocity values decrease again, down to $\sim 8.16 \mathrm{~km} / \mathrm{s}$ at $400 \mathrm{~km}$.

Difference between observed and theoretical travel times from 3D model is mainly caused by model inaccuracy. Differences between blue line and blue dots (Fig. 5b) can be characterized by $\mathrm{RMS}=1.12 \mathrm{~s}$.

Because rays mostly travel through the uppermost mantle, the influence of $\mathrm{P}$-wave velocity modification on travel time fit was tested for all stations (LUMP+" 13 BB Star" + PLSN). Figure 6 (with legend in Table 1) shows absolute travel time difference (colour scale) for different uppermost-mantle velocity modifications (UMM velocity factor; vertical scale, from $+3 \%$ in the bottom, to $-7 \%$ on top) for each station (horizontal scale, one column per station, stations sorted by distance from source, separately for each station group). White dots show velocity change providing the best time fit for each station. Seismic wave from source to closest PLSN station (NIE) did not propagate in the uppermost mantle, so for this station travel time accuracy does not change with modification of the uppermost mantle velocity.

Although seismic records from $13 \mathrm{BB}$ and PLSN presented in Fig. 6 do not help with modelling along the LUMP profile, they were used in general for 3D model verification. We cannot assume that the model of Grad et al. (2016) has too high P-wave velocities below the Moho for other directions of wave propagation. To exclude the fact that these velocities are too high for the whole model, we show that for PLSN for two stations its values are too small and for one station the travel time difference is really small.

\section{Testing Vp in the lower lithosphere}

For modelling of the $\mathrm{P}$ phase, we used travel time inversion, which is a commonly used method that allows to reconstruct seismic velocity model basing on the observations of the arrival times of seismic phases. In this paper, we used the Rayinvr program (Zelt 1999) modified by Gorman (2002). This program assumes isotropic, two-dimensional medium, consisting of layers with smoothly varying $\mathrm{P}$-wave velocities, with possible velocity discontinuities at the layer boundaries. The velocity in each layer is parameterized on a trapezoidal grid at user-defined nodes, with linear interpolation between neighbouring nodes to obtain the velocity field at any point of the model. As an initial model, usually a simple 1D velocity field is used. For the calculation of travel times and ray paths (ray theory approximation), numerical solution of eikonal equations for two-dimensional media by the Runge-Kutta method is performed. Differences (residuals) between the observed travel time data and travel times calculated for the current model represent the input for linearized damped least squares inversion procedure. Inversion results in corrections of the velocity model that improve the fit to the observed data. Usually, several iterations of the inversion and of model corrections are needed, and inversion is stopped when RMS travel time residual is on the level of estimated data (picking) errors.

Using this tool we estimated a new P-wave velocity model for the LUMP profile (Fig. 7a). We assumed crustal velocities after Grad et al. (2016) as it is shown in Fig. 5a. Tracing $\mathrm{P}$-wave propagation, we focused only on the uppermost mantle below Moho. To analyse model incompatibilities, we create a new model using $2 \mathrm{D}$ forward seismic modelling with starting Model X which had velocity from $8.05 \mathrm{~km} / \mathrm{s}$ just beneath the Moho to $8.17 \mathrm{~km} / \mathrm{s}$ at the depth of $60 \mathrm{~km}$ (Fig. 7b), which significantly improved the propagation of deep rays. Model X was used as a starting model in inversion analysis.

In order to limit the ambiguity of the solution, the velocities in the crust and the Moho depth were assumed to be known based on 3D well-documented model and were not subject to inversion. Therefore, only the uppermost mantle velocities were modelled. The velocities were parameterized in nodes with $\sim 5 \mathrm{~km}$ step. In general, with a single source, the ray distribution is unfavourable for inversion, but as ray paths in the modelled layer have different length, they still provide some independent information. Therefore, we decided to use such a simple inversion procedure to evaluate the mantle velocities.

After three steps of inversion, we obtain Model Y (Fig. 7a). Accuracy of fitting the data is shown in Fig. 7c. The RMS value after inversion is 0.23 . Model $\mathrm{Y}$ has two areas with relatively higher P-wave velocity, $\sim 8.16 \mathrm{~km} / \mathrm{s}$ at $275 \mathrm{~km}$ and $\sim 8.15 \mathrm{~km} / \mathrm{s}$ at $380 \mathrm{~km}$, and two with lower, $7.90 \mathrm{~km} / \mathrm{s}$ at $350 \mathrm{~km}$ and $7.95 \mathrm{~km} / \mathrm{s}$ at $400 \mathrm{~km}$ (Fig. 7b). P-wave velocity is significantly lower than that in the model of Grad et al. (2016). This change improved coverage of rays propagation in the uppermost mantle. (Earlier crossing profiles have higher P-wave velocity in the uppermost mantle.)

\section{Trial-and-error forward modelling}

Based on data from intersections with 14 wide-angle reflection and refraction profiles conducted earlier, a velocity distribution model of P-waves, here model Z (Fig. 8a), was constructed along the LUMP profile (Fig. 2). Since the construction of Model $\mathrm{Z}$ includes slightly more or different data variants, as well as another interpolation method, in some details this model differs from the models presented 

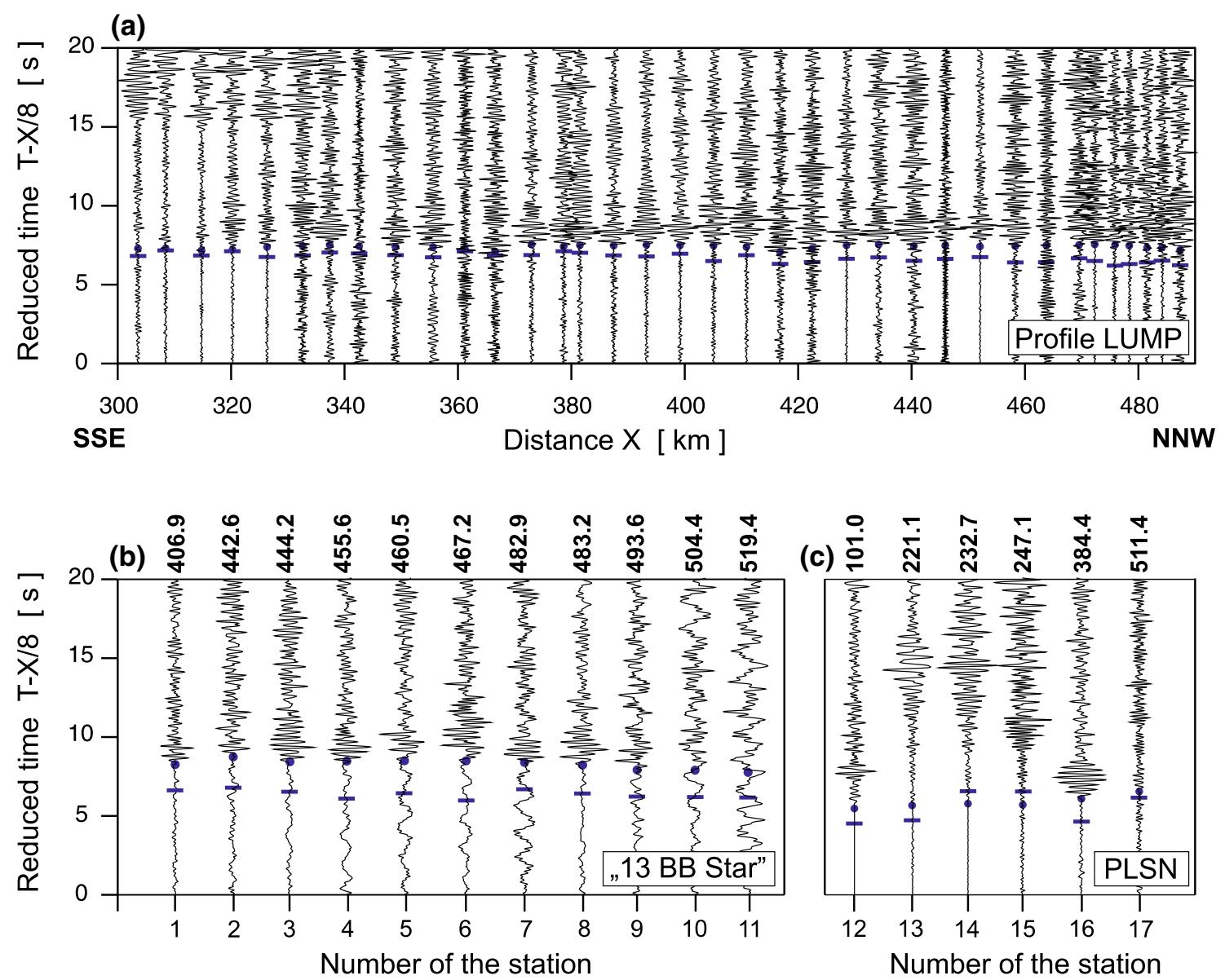

(d)

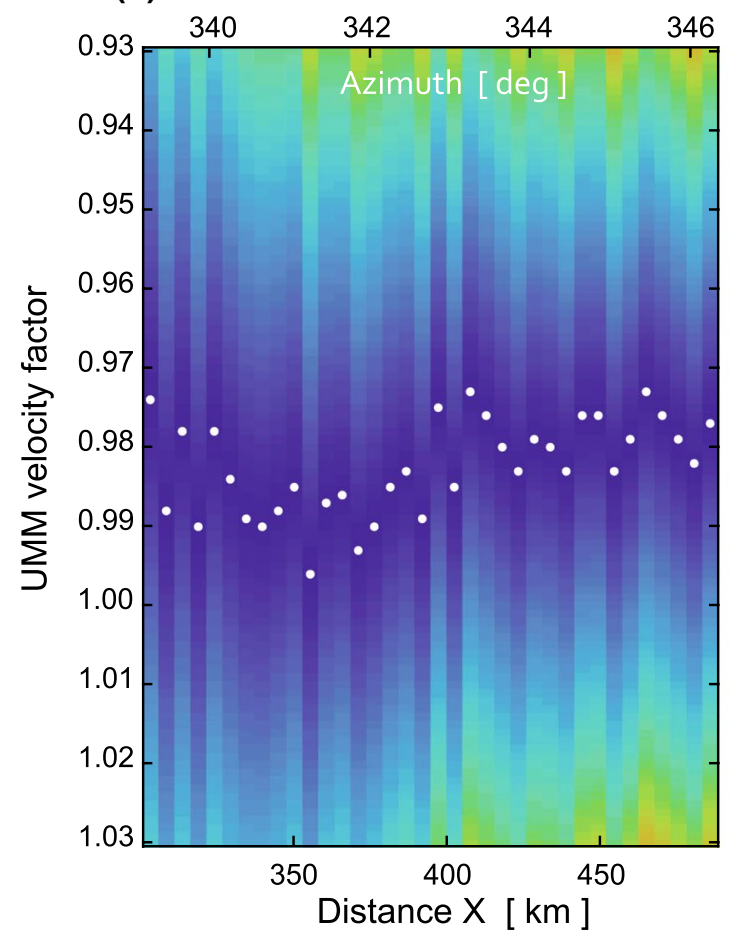

(e) „13 BB Star”

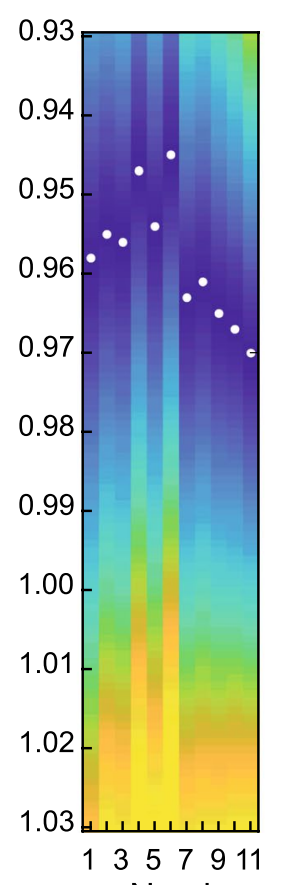

(f) PLSN

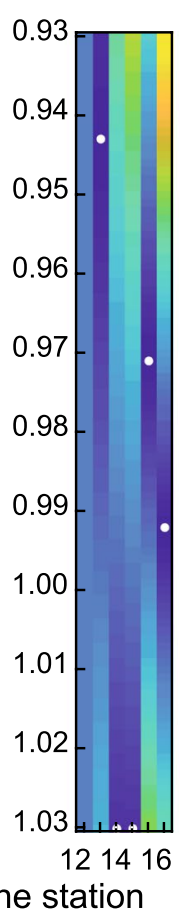
Number of the station
$\Delta \mathrm{T}[\mathrm{s}]$

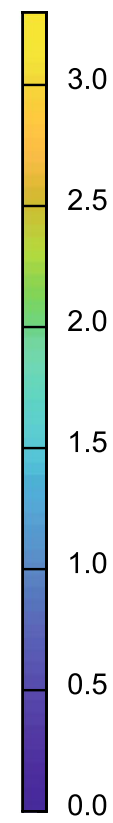


4Fig. 6 Seismic section with travel times calculated with the 3D model (blue dashes) and first arrivals (blue dots) for a the LUMP profile, filtration $1.5-6.0 \mathrm{~Hz}, \mathbf{b}$ 13BB Star, filtration $0.5-6.0 \mathrm{~Hz}$, c PLSN stations, filtration 1.5-6.0 Hz. Differences between observed and theoretical travel time from 3D model for: $\mathbf{d}$ the LUMP profile, e 13BB Star, f PLSN stations

earlier (Model X and Model Y). Taking into account the complexity of data from so many profiles crossing the LUMP profile from different angles, it is possible to understand the complexity of the crustal part of the model. This is an alternative model to presented earlier Model Y (Fig. 7a). In the modelling process, the crustal part of the model was frozen (assumed to be constant), as well as the shape of the Moho boundary. The Moho depth changes along the model from about $32 \mathrm{~km}$ in SSE to $42 \mathrm{~km}$ in NNW. Beneath many profiles crossing TESZ, we observe a very well-documented high-velocity $\mathrm{Vp}$ under the Moho boundary; for example, on TTZ-PL profile $\mathrm{Vp}$ is $\sim 8.4 \mathrm{~km} / \mathrm{s}$ (Grad et al. 1999; Janik et al. 2005). On profiles which cross the LUMP profile at a greater angle, the velocities are similar or slightly lower: CEL02 $\sim 8.25 \mathrm{~km} / \mathrm{s}$ (Malinowski et al. 2005); S05 8.35 km/s (Janik, under preparation); CEL21 8.4 km/s (Janik et al. 2009); CEL14 $8.4 \mathrm{~km} / \mathrm{s}$ (Środa et al. 2006); LT-5 $\sim 8.35 \mathrm{~km} / \mathrm{s}$ (Guterch et al. 1986; Grad et al. 2005); CEL10 7.9 (8.2) km/s (Hrubcova et al. 2008; Grad et al. 2009a; Janik, not published); LT-4 $\sim 8.35 \mathrm{~km} / \mathrm{s}$ (Guterch et al. 1986; Grad et al. 2005); S01 $\sim 8.35 \mathrm{~km} / \mathrm{s}$ (Grad et al. 2008); P4 8.4 km/s (Grad et al. 2005). In the northern part of the model, where the profile enters the EEC, observed Vp velocities are slightly lower: LT-2 $8.1 \mathrm{~km} / \mathrm{s}$ (Guterch et al. 1986; Grad et al. 2005); P2 $~ 8.15 \mathrm{~km} / \mathrm{s}$ (Janik et al. 2002); LT-7 $8.2 \mathrm{~km} / \mathrm{s}$ (Guterch et al. 1994); P3 $8.05 \mathrm{~km} / \mathrm{s}$ (Środa and POLONAISE Working Group 1999).

The crustal part of Model Z, as well as the shape of the Moho boundary, was assumed to be constant in the modelling process. Only the velocities in the uppermost mantle were modelled. The trial-and-error forward modelling was carried out with the SEIS83 package (Červený and Pšenčík 1984) together with its graphical interface model (Komminaho 1998) and ZPLOT software (Zelt 1994). In the first step, the P-wave computed with $\mathrm{Vp} \sim 8.4 \mathrm{~km} / \mathrm{s}$ for the whole uppermost mantle, arrived approximately $1.0 \mathrm{~s}$ earlier than the recorded signals, similar to the model of Grad et al. (2016) presented in Fig. 5b. Modifications of the uppermost mantle tested in many subsequent steps of the trial-and-error modelling led to the model shown in Fig. 8a. Just below the Moho, up to $330 \mathrm{~km}$ of the Model Z, there is a layer of thickness $4-12 \mathrm{~km}$ and $\mathrm{Vp} \sim 8.25-8.3 \mathrm{~km} / \mathrm{s}$. This value is slightly lower than that suggested by the intersected profiles, but more similar to the Vp occurring on CEL04 profile $(\mathrm{Vp}=8.1-8.35 \mathrm{~km} / \mathrm{s}$, Środa et al. 2006) located near parallel to the southern part of the LUMP profile (90-40 km to the east). This may indicate the presence of directional anisotropy in this layer. According to data from other profiles, at a distance of $330-505 \mathrm{~km}$, the velocity in this layer is $\mathrm{Vp}=8.05-8.1 \mathrm{~km} / \mathrm{s}$. Under this layer in the entire length of the Model $\mathrm{Z}$, we assumed the existence of a layer with lower velocities. (In case of $\mathrm{Vp}$ of $8.0-8.1 \mathrm{~km} / \mathrm{s}$, its thickness should be $\sim 17-20 \mathrm{~km}$.) At a depth of about $55 \mathrm{~km}$, another boundary was modelled, under which $\mathrm{Vp}>8.35 \mathrm{~km} / \mathrm{s}$. At distances of $170-350 \mathrm{~km}$ of the Model $\mathrm{Z}$, this boundary is dipping into $70 \mathrm{~km}$. Modifications were done to bring theoretical travel times into accordance with the correlations of the $\mathrm{P}_{\text {mantle }}$ wave observed on the recorded section on the LUMP profile, at offset between 300 and $490 \mathrm{~km}$.

For searching S-waves travel times, we used Model Z obtained from $\mathrm{P}$-waves, applying a $\mathrm{Vp} / \mathrm{Vs}$ ratio individually for each layer. Due to the quality of the data we had, we limited ourselves to general modelling of the $\mathrm{Vp} / \mathrm{Vs}$ ratio. Modelling assumed $\mathrm{Vp} / \mathrm{Vs}=1.73$ for the whole Model Z, except for the two deepest layers where $\mathrm{Vp} / \mathrm{Vs}=1.74$. This allows us to show $\mathrm{P}_{\text {mantle }}$ together with expected $\mathrm{S}_{\text {mantle }}$ phases from below the last boundary in Model $\mathrm{Z}$. The modelled travel times for both $\mathrm{P}$ - and $\mathrm{S}$-waveforms are derived from phases multiple reflected from middle and/or lower crust penetrating the selected layers. In general, they fit quite well with the area of the amplitude increase observed in the seismic section.

Model $\mathrm{Z}$ is an alternative to Model Y presented earlier (Fig. 7a). Its assumptions are in line with the previously collected velocity information and the belief that under the TESZ there is a uniform high-velocity layer just beneath the Moho. Model Z contrasts with the Model Y, where just under the Moho we observe a huge lateral variation of the velocity values for $\mathrm{P}$-waves.

\section{Discussion and conclusions}

We raised the question: Are we able to draw important conclusions about the structure thank to such a small experiment as LUMP profile? The answer is: Yes, we are. We are aware of the fact that we only make the previous model more detailed but we show corrected Vp distribution below Moho in central Poland. By analysing the P-wave velocities in the uppermost mantle beneath the central part of Poland, beneath the models parallel to LUMP profile, we observe much lower values than we would expect from previous investigations in the region. In the first presented model (Fig. 5a) based on the velocity data set prepared by Grad et al. (2016), the values from $8.27 \mathrm{~km} / \mathrm{s}$ at $50 \mathrm{~km}$ of the profile or $8.32-8.36 \mathrm{~km} / \mathrm{s}$ in its central part do not fit the first arrivals on seismic section. 

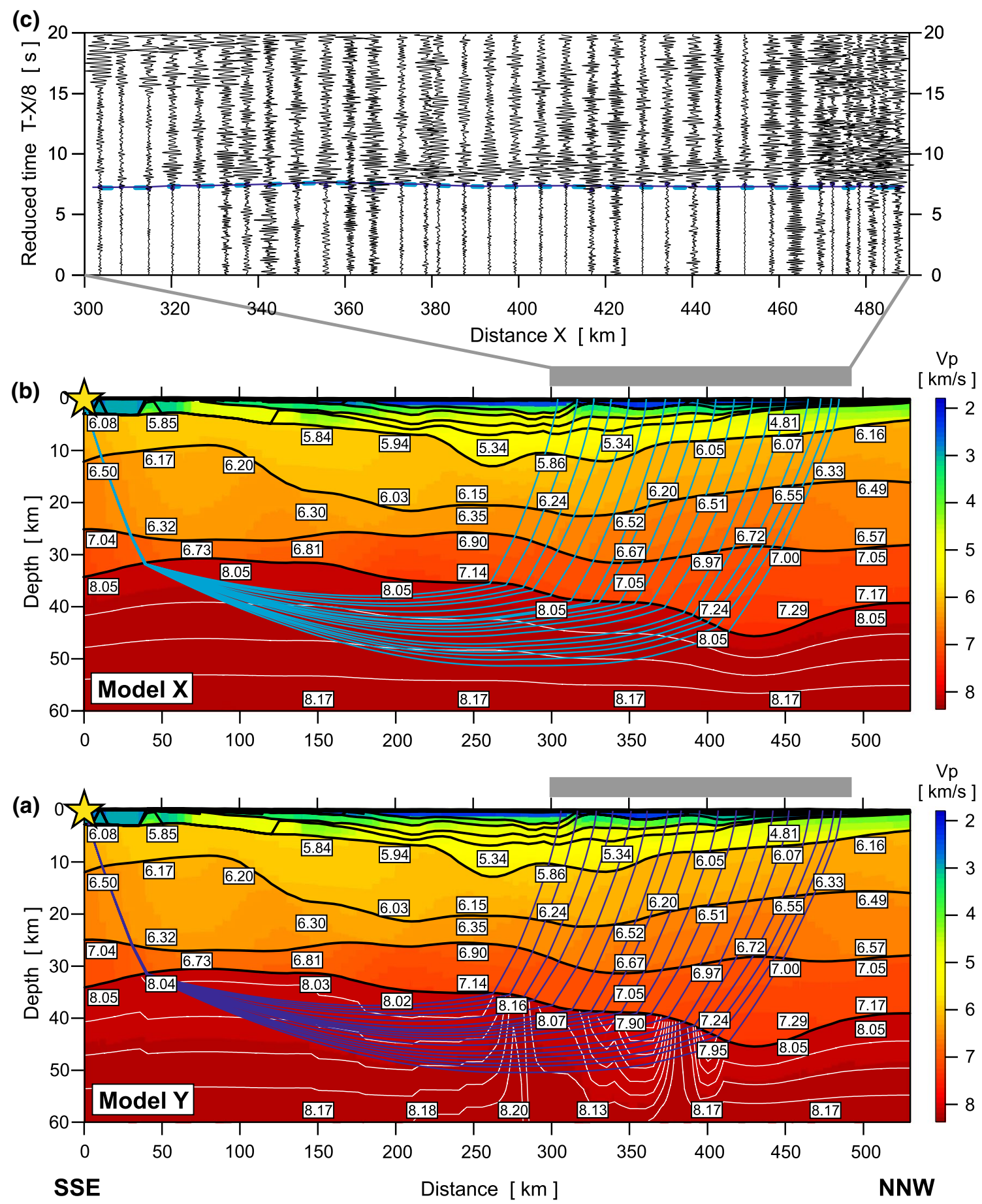

Fig. 7 a The Model Y of the LUMP profile obtained by seismic inversion (Model Y). Thick, black lines represent velocity discontinuities (interfaces). Velocity values in $\mathrm{km} / \mathrm{s}$ are shown in white boxes. Thin, white lines represent velocity contour lines (each $0.03 \mathrm{~km} / \mathrm{s}$ ). Blue lines correspond to ray paths. b The Model X-vertical cross section obtained from 3D model of $\mathrm{P}$-wave velocity in Poland

Model X was composed using 2D forward seismic modelling and changing model beneath the Moho into one layer with $\mathrm{Vp} \sim 8.05 \mathrm{~km} / \mathrm{s}$ in the top and $8.17 \mathrm{~km} / \mathrm{s}$ at $60 \mathrm{~km}$ between event location and middle point of the LUMP profile with Model X below the Moho discontinuity. c Seismic section with calculated travel times: navy blue line-for the new model presented in a; light blue dashed line-for model (b), and first arrivals (navy blue dots), filtration $1.5-6.0 \mathrm{~Hz}$

depth, which significantly improved travel times fit to the data (Fig. 7b). Optimizing this model by using inversion, we obtain the best results for Model Y with two higher 

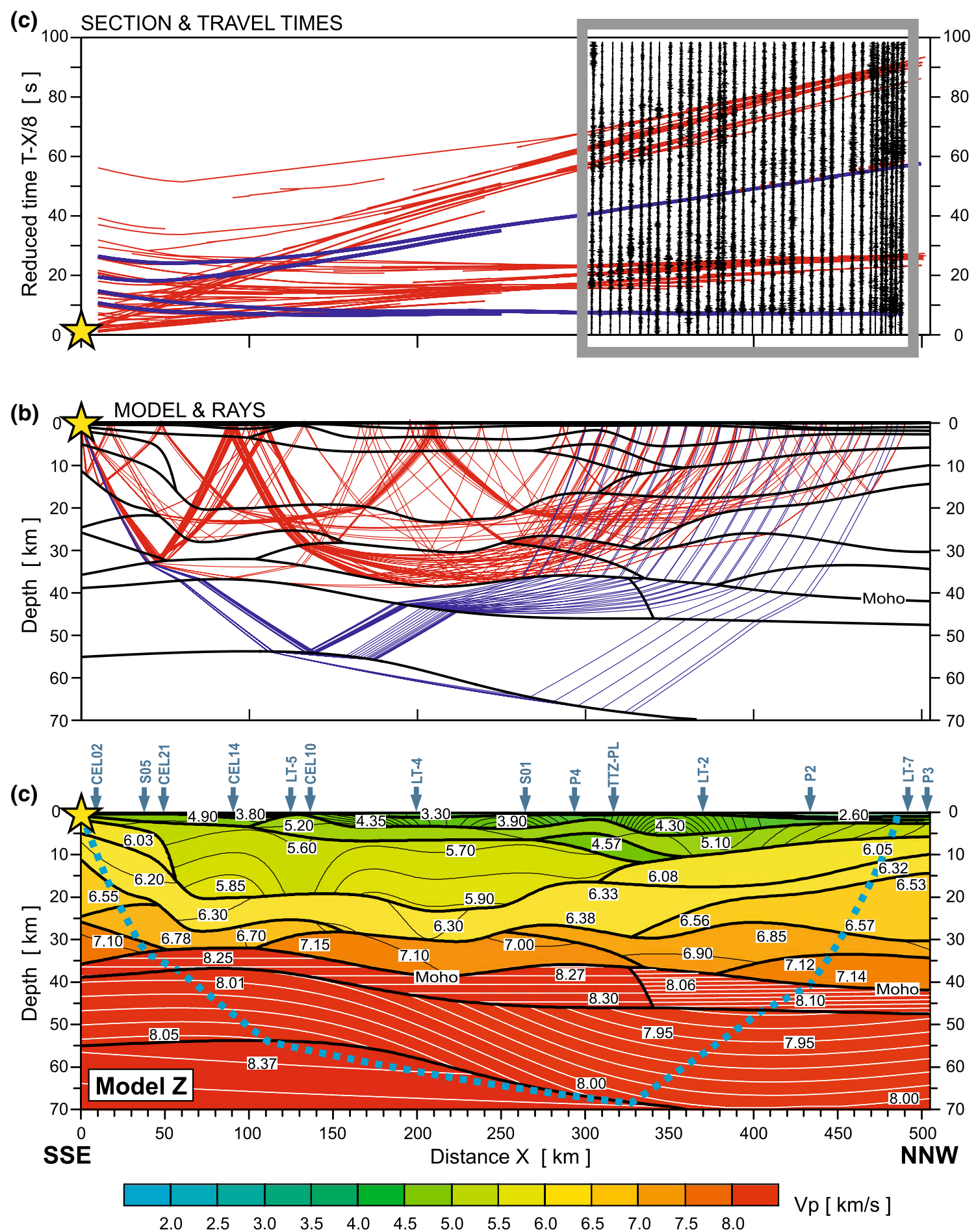

Fig. 8 a The Model Z-2D ray-tracing P-wave velocity model for the LUMP profile. Please note that the crustal part of the model is constructed from models listed in Table 2, which cross the LUMP profile. Only velocities in the uppermost mantle were modelled. Thick, black lines represent velocity discontinuities (interfaces). Thin black lines represent velocity contour lines in the crust (each $0.1 \mathrm{~km} / \mathrm{s}$ ). Thin white lines represent velocity contour lines under Moho (each $0.01 \mathrm{~km} / \mathrm{s}$ ). Blue lines correspond to ray paths. Blue dashed line cor- responds to the range of ray propagation. Velocity values in $\mathrm{km} / \mathrm{s}$ are shown in white boxes. b The ray paths refracted and reflected at crustal uppermost mantle discontinuities with multiples. c Seismic sections with travel times calculated for the model presented in a. d Enlargement of seismic section from grey frame presented in Fig. 8c, filtration $0.5-9.0 \mathrm{~Hz}$. Red rays on $\mathbf{b}$ red travel times on $\mathbf{c}$ and $\mathbf{d}$ diagrams represent selected crustal multiples which can explain high amplitudes after first arrivals. They are not included in modelling 


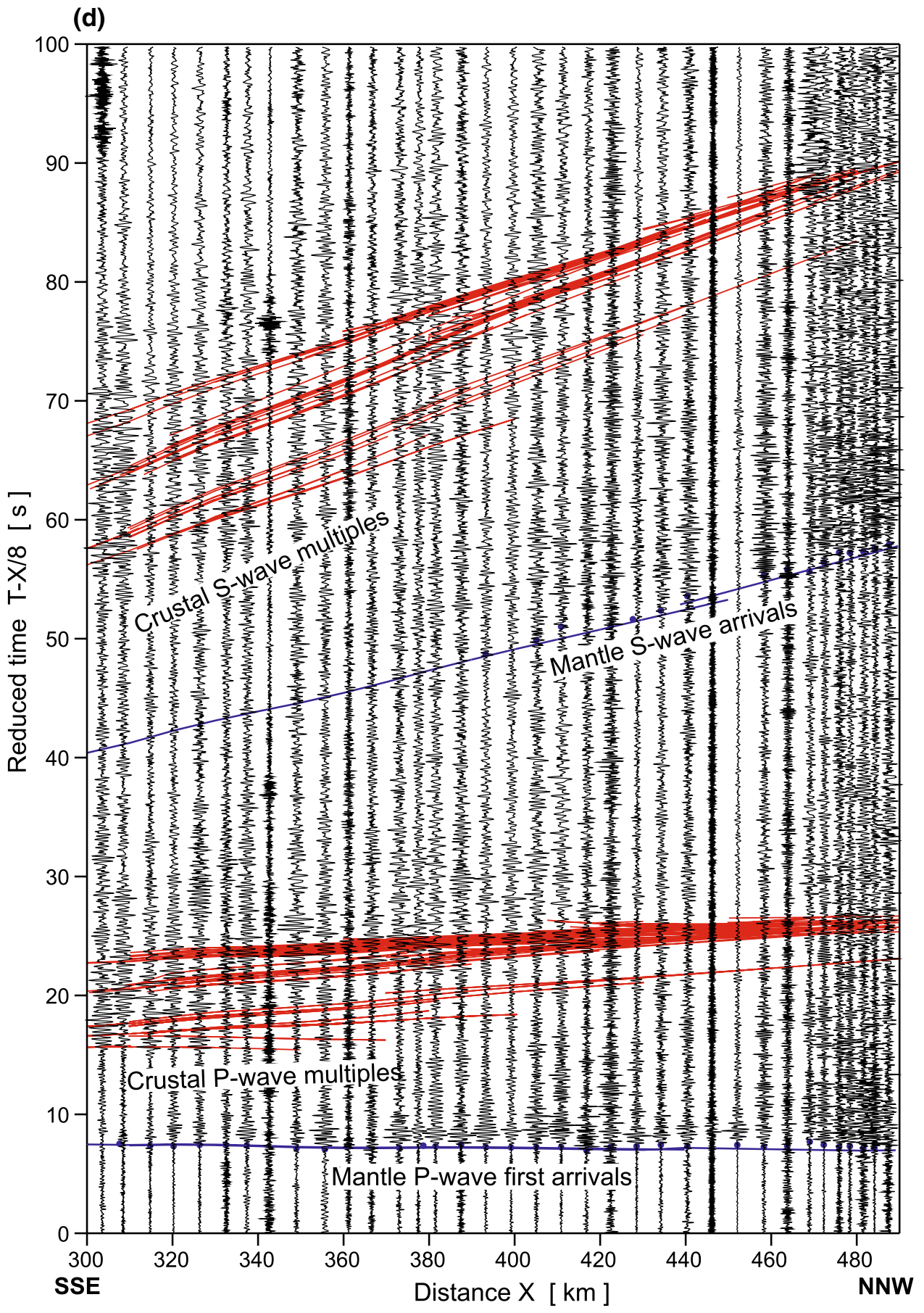

Fig. 8 (continued)

P-wave velocity areas, $8.16 \mathrm{~km} / \mathrm{s}$ at $275 \mathrm{~km}$ and $8.15 \mathrm{~km} / \mathrm{s}$ at $380 \mathrm{~km}$, and two lower areas, $7.90 \mathrm{~km} / \mathrm{s}$ at $350 \mathrm{~km}$ and $7.95 \mathrm{~km} / \mathrm{s}$ at $400 \mathrm{~km}$ (Fig. 7a). This change also let rays to propagate deeper.

Both these solutions, "island nature" of high-velocity uppermost mantle and relatively low-velocity values, appear to be unrealistic as they essentially depart from the upper mantle structure presented on profiles that intersect the LUMP profile. Not all of them have equal proof in data, but particularly the TTZ and P4 profiles have extensive areas of well-documented high-velocity upper mantle $\mathrm{Vp} \sim 8.25 \mathrm{~km} / \mathrm{s}$ and $\mathrm{Vp} \sim 8.4 \mathrm{~km} / \mathrm{s}$, respectively. A similarly well-documented high-velocity area occurs on the P1 profile (Jensen et al. 1999). It is difficult to imagine that the LUMP profile just between them had so much lower velocity in the upper mantle. Considering this, a compromise 
model was proposed. It assumes the existence of a highvelocity layer directly below the Moho boundary with $\mathrm{Vp} \sim 8.25 \mathrm{~km} / \mathrm{s}$, which is the lowest of the high-velocity values observed on crossed profiles up to a distance of $\sim 300 \mathrm{~km}$ and $\mathrm{Vp} \sim 8.1 \mathrm{~km} / \mathrm{s}$ to the end of the profile. On the other hand, it was necessary to significantly delay the arrival times of theoretical travel times to match the times observed in our seismic section (Fig. 8c). In the trial-and-error modelling, many different variants of solutions were tested to achieve $\sim 1 \mathrm{~s}$ time delay effect of $\mathrm{P}_{\text {mantle }}$ wave. As a result, the solution presented in the Model Z in Fig. 8a was adopted. The uppermost mantle has three layers. The first two parts, directly under the border of the Moho, have a thickness of 4-12 km with $\mathrm{Vp}=8.2-8.3 \mathrm{~km} / \mathrm{s}$ to about $330 \mathrm{~km}$ of profile and further with $\mathrm{Vp}=8.04-8.12 \mathrm{~km} / \mathrm{s}$. The P-wave running in this layer reaches maximum offset shorter than the observation interval of our seismic section. Postponed delay was achieved by adding 15-23 km-thick low-velocity zone beneath the first boundary (Fig. 8a) $(\mathrm{Vp} \sim 8.03 \mathrm{~km} / \mathrm{s}$ at the beginning of the profile, $\sim 8.0 \mathrm{~km} / \mathrm{s}$ in the middle and $7.97 \mathrm{~km} / \mathrm{s}$ at the end of the profile). Next layer which produces the observed $\mathrm{P}_{\text {mantle }}$ travel times requires higher velocities beneath this layer $(8.37 \mathrm{~km} / \mathrm{s})$. To fit the data, this lower layer is observed at a depth of $\sim 55 \mathrm{~km}$ at a distance up to $150 \mathrm{~km}$. It gently deepens up to a distance of $\sim 350 \mathrm{~km}$ to finally disappear at $70 \mathrm{~km}$ depth. Wave propagation cannot verify its existence at further distances.

Model Z, i.e. the 2D seismic forward model calculated for the LUMP profile, confirms that the existence of a relatively thin layer with $\sim 8.25 \mathrm{~km} / \mathrm{s}$ P-wave velocity just below the Moho boundary is possible, but it requires lower velocity layer above next boundary with $\mathrm{Vp} \sim 8.37 \mathrm{~km} / \mathrm{s}$ at depths of $55-65 \mathrm{~km}$. Due to the fact that there is a low-velocity zone, it is impossible to determine accurately its values. There is a possibility to assume a class of other solutions with thinner layers with lower P-wave velocity and changed depth of the deepest boundary, respectively. Previous profiles crossing the TTZ from SW to NE have indicated higher P velocity, $\sim 8.4 \mathrm{~km} / \mathrm{s}$ (e.g. Guterch et al. 1994; Grad et al. 2003). Also teleseismic P-wave tomography results of PASSEQ data show lower P-wave velocity values to the west of the TESZ and higher ones to the east of it (Janutyte et al. 2015). Typically, the waves in the Precambrian lithosphere sections are considered to move faster than in their younger counterparts.

We claim that in the direction of the LUMP profile (SSE$\mathrm{NNW}$ ) the P-wave velocity should be reduced to $\sim 8.1 \mathrm{~km} / \mathrm{s}$ beneath Moho or assuming higher velocities $(\sim 8.25 \mathrm{~km} / \mathrm{s}$, more consistent with velocities observed on crossing profiles), and there is a need to add a low-velocity zone below and a higher velocity layer $(\mathrm{Vp} \sim 8.37 \mathrm{~km} / \mathrm{s})$ beneath it. Such a reduced $\mathrm{P}$-wave velocity in the uppermost mantle can be explained by directional anisotropy. Another conclusion is that there emerges a possibility of a more complicated upper mantle structure under the LUMP profile in the southern part of Poland than in previously accepted models, where P-wave velocities are not so well documented as in the northern part. Anyway, the analysis of these data shows how carefully and critically we have to consider the previously calculated 2D models as well as 3D models based on them (Majdański 2012; Grad et al. 2016), especially in the uppermost mantle. We have to take into account their imperfections (limited or not the best quality of data).

In this paper, we did not analyse details of S-wave velocity distribution. We assumed only $\mathrm{Vp} / \mathrm{Vs}=1.73$ for most of the model and $\mathrm{Vp} / \mathrm{Vs}=1.74$ for the two deepest layers. Relatively weak S-wave arrivals can be explained by the full moment tensor solution, which shows that the earthquake had normal faulting on a north-west-striking plane and very high double-couple component caused pure shear tensor.

The complex area has been studied repeatedly. The research projects were aimed at getting to know the geology and tectonics of the TESZ zone in different areas. The origin and further evolution of this area are still the subject of research and are still not yet fully understood, but every piece of information is verifying another structural fragment and should be added to previous/other research. New models of the uppermost mantle velocity do not change tectonic implications; however, the velocities should be corrected beneath the TESZ area. Such information is useful, for example, in petrological and gravimetrical studies.

Acknowledgements Participation of the group from the Institute of Geophysics PAS in this work was supported within statutory activities No. 3841/E-41/S/2017 of the Ministry of Science and Higher Education of Poland and by National Science Centre in Poland - Grant DEC2011/02/A/ST10/00284. Some of the presented figures were prepared with Generic Mapping Tool package (Wessel and Smith 1995). We would like to thank three anonymous reviewers whose comments significantly improved this paper.

Open Access This article is distributed under the terms of the Creative Commons Attribution 4.0 International License (http://creativeco mmons.org/licenses/by/4.0/), which permits unrestricted use, distribution, and reproduction in any medium, provided you give appropriate credit to the original author(s) and the source, provide a link to the Creative Commons license, and indicate if changes were made.

\section{References}

BABEL Working Group (1993) Deep seismic reflection/refraction interpretation of crustal structure along BABEL profiles A and B in the southern Baltic Sea. Geophys J Int 112:325-343

Babuška V, Montagner JP, Plomerová J, Girardin N (1998) Agedependent large-scale fabric of the mantle lithosphere as derived from surface-wave velocity anisotropy. Pure Appl Geophys 151(2):257-280

Blundell D, Freeman R, Mueller S (eds) (1992) A continent revealed: the European Geotraverse. Cambridge, Cambridge University Press, p 275 
Bogdanova SV, Gorbatschev R, Stephenson RA (2001) EUROBRIDGE: Paleoproterozoic accretion of Fennoscandia and Sarmatia. Tectonophysics 339:7-10

Bogdanova SV, Gorbatschev R, Garetsky RG (2005) The East European Craton. In: Selley RC, Cocks LRM, Plimer IR (eds) Encyclopedia of geology, vol 2. Elsevier, Amsterdam, pp 34-49

Bogdanova S, Gorbatschev R, Grad M, Guterch A, Janik T, Kozlovskaya E, Motuza G, Skridlaite G, Starostenko V, Taran L, EUROBRIDGE, POLONAISE Working Groups (2006) EUROBRIDGE: new insight into the geodynamic evolution of the East European Craton. In: Gee DG, Stephenson RA (eds) European lithosphere dynamics, vol 32. Geological Society of London Memoirs, London, pp 599-625

Bukowska M (2012) The rockbursts in the Upper Silesian Coal Basin in Poland. J Min Sci 3:445-456

Buła Z, Żaba J, Habryn R (2008) Tectonic subdivision of Poland: southern Poland (Upper Silesian Block and Małopolska Block). Prz Geol 56:912-920 (in Polish, English summary)

Červený V, Pšenčík I (1984) SEIS83-Numerical modelling of seismic wave fields in 2-D laterally varying layered structures by the ray method. In: Documentation of earthquake algorithms by ER Engdahl. World Data Center (A) for Solid Earth Physics, Report SE-35, pp 36-40

Cymerman Z (2007) Does the Mazury dextral shear zone exist? PrZ Geol 55:157-167 (in Polish with English abstract)

EUGENO-S Working Group (1988) Crustal structure and tectonic evolution of the transition between the Baltic Shield and the North German Caledonides (the EUGENO-S Project). Tectonophysics 150:253-348

Franke W (2014) Topography of the Variscan orogen in Europe: failednot collapsed. Int J Earth Sci 103:1471-1499

Gee DG, Zeyen HJ (eds) (1996) EUROPROBE 1996-Lithospheric dynamics: origin and evolution of continents. the EUROPROBE Secretariate, Uppsala University, Uppsala, p 138

Gorman AR (2002) Ray-theoretical seismic traveltime inversion: modifications for a two-dimensional radially parametrized Earth. Geophys J Int 151:511-516

Grad M, Janik T, Yliniemi J, Guterch A, Luosto U, Komminaho K, Środa P, Höing K, Makris J, Lund CE (1999) Crustal structure of the Mid Polish Trough beneath TTZ seismic profile. Tectonophysics 314(1-3):145-160

Grad M, Keller GR, Thybo H, Guterch A, POLONAISE Working Group (2002) Lower lithospheric structure beneath the TransEuropean Suture Zone from POLONAISE'97 seismic profiles. Tectonophysics 360:153-168

Grad M, Jensen SL, Keller GR, Guterch A, Thybo H, Janik T, Tiira T, Yliniemi J, Luosto U, Motuza G, Nasedkin V, Czuba W, Gaczyński E, Środa P, Miller KC, Wilde-Piórko M, Komminaho K, Jacyna J, Korabliova L (2003) Crustal structure of the Trans-European suture zone region along POLONAISE'97 seismic profile P4. J Geophys Res 108(B11):2541. https://doi. org/10.1029/2003JB002426

Grad M, Guterch A, Polkowska-Purys A (2005) Crustal structure of the Trans-European Suture Zone in Central Poland: reinterpretation of the LT-2, LT-4 and LT-5 deep seismic sounding profiles. Geol Q 49(3):243-252

Grad M, Guterch A, Keller GR, Janik T, Hegedüs E, Vozar J, Ślączka A, Tiira T, Yliniemi J (2006) Lithospheric structure beneath transCarpathian transect from Precambrian platform to Pannonian basin: CELEBRATION 2000 seismic profile CEL05. J Geophys Res 111:B03301

Grad M, Guterch A, Mazur S, Keller GR, Špičák A, Hrubcová P, Geissler WH, SUDETES 2003 Working Group (2008) Lithospheric structure of the Bohemian Massif and adjacent Variscan belt in central Europe based on Profile S01 from the SUDETES
2003 experiment. J Geophys Res 113:B10304. https://doi. org/10.1029/2007JB005497

Grad M, Brückl E, Majdański M, Behm M, Guterch A, CELEBRATION 2000, ALP 2002 Working Groups (2009a) Crustal structure of the Eastern Alps and their foreland: seismic model beneath the CEL10/Alp04 profile and tectonic implications. Geophys J Int 177:279-295

Grad M, Tiira T, ESC Working Group (2009b) The Moho depth map of the European Plate. Geophys J Int 176:279-292. https://doi. org/10.1111/j.1365-246X.2008.03919.x

Grad M, Polkowski M, Wilde-Piorko M, Suchcicki J, Arant T (2015) Passive seismic experiment " 13 BB Star" in the margin of the East European craton, northern Poland. Acta Geophys 63(2):352-373

Grad M, Polkowski M, Ostaficzuk SR (2016) High-resolution 3D seismic model of the crustal and uppermost mantle structure in Poland. Tectonophysics 666:188-210

Guterch A, Grad M, Materzok R, Perchuć E (1986) Deep structure of the Earth's crust in the contact zone of the Palaeozoic and Precambrian platforms in Poland (Tornquist-Teisseyre Zone). Tectonophysics 128:251-279

Guterch A, Grad M, Janik T, Materzok R, Luosto U, Yliniemi J, Lück E, Schulze A, Förste K (1994) Crustal structure of the transition zone between Precambrian and Variscan Europe from new seismic data along LT-7 profile (NW Poland and eastern Germany). C R Acad Sci Paris 319(serie II):1489-1496

Guterch A, Grad M, Thybo H, Keller GR (1997) POLONAISE'97International seismic experiment. Terra Nostra 11:56-66

Guterch A, Grad M, Thybo H, Keller GR, POLONAISE Working Group (1999) POLONAISE'97-International seismic experiment between Precambrian and Variscan Europe in Poland. Tectonophysics 314:101-121

Guterch A, Grad M, Keller GR, Posgay K, Vozar J, Spicak A, Brueckl E, Hajnal Z, Thybo H, Selvi O, CELEBRATION 2000 Experiment Team (2003) CELEBRATION 2000 seismic experiment. Studia Geophys Geod 47:659-669

Guterch A, Wybraniec S, Grad M, Chadwick RA, Krawczyk CM, Ziegler PA, Thybo H, Voss WD (2010) Crustal structure and structural framework. In: Doornenbal JC, Stevenson AG (eds) Petroleum geological atlas of the Southern Permian Basin area. EAGE Publications, Houten, pp 11-23

Hrubcova P, Środa P, CELEBRATION 2000 Working Group (2008) Crustal structure at the easternmost termination of the Variscan belt based on CELEBRATION 2000 and ALP 2002 data. Tectonophysics 460:55-75

Janik T, Yliniemi J, Grad M, Thybo H, Tiira T, POLONAISE P2 Working Group (2002) Crustal structure across the TESZ along POLONAISE' 97 seismic profile P2 in NW Poland. Tectonophysics 360:129-152

Janik T, Grad M, Guterch A, Dadlez R, Yliniemi J, Tiira T, Keller GR, Gaczyński E, CELEBRATION 2000 Working Group (2005) Lithospheric structure of the Trans-European Suture Zone along the TTZ and CEL03 seismic profiles (from NW to SE Poland). Tectonophysics 411:129-156. https://doi.org/10.1016/j.tecto 2005.09.005

Janik T, Grad M, Guterch A, CELEBRATION 2000 Working Group (2009) Seismic structure of the lithosphere between the East European Craton and the Carpathians from the net of CELEBRATION 2000 profiles in SE Poland. Geol Q 53(1):141-158

Janutyte I, Majdanski M, Voss PH, Kozlovskaya E, PASSEQ Working Group (2015) Upper mantle structure around the Trans-European Suture Zone obtained by teleseismic tomography. Solid Earth 6:73-91. https://doi.org/10.5194/se-6-73-2015

Jensen SL, Janik T, Thybo H, POLONAISE Working Group (1999) Seismic structure of the Palaeozoic Platform along 
POLONAISE'97 profile P1 in NW Poland. Tectonophysics 314(1-3):123-144

Knopoff L, Randall MJ (1970) The compensated linear-vector dipole: a possible mechanism for deep earthquakes. J Geophys Res 75:1957-1963

Komminaho K (1998) Software manual for programs MODEL and XRAYS: a graphical interface for SEIS83 program package. University of Oulu, Department of Geophysics, Report 20, p 31

Kwiatek G, Martínez-Garzón P, Bohnhoff M (2016) HybridMT: A MATLAB/shell environment package for seismic moment tensor inversion and refinement. Seismol Res Lett. https://doi. org $/ 10.1785 / 0220150251$

Lund B (2015) The blast 2015-11-18 (personal communication)

Lund CE, Prodehl C, Kaminski W, Guggisberg B, Ansorge J (1983) A preliminary interpretation of the long-range seismic refraction profile (Fennolora) through Scandinavia. Geol Fören Stockh Förh 105(4):388-388

Majdański M (2012) The structure of the crust in TESZ area by Kriging interpolation. Acta Geophys 60(1):59-75. https://doi.org/10.2478/ s11600-011-0058-5

Malinowski M, Żelaźniewicz A, Grad M, Guterch A, Janik T, CELEBRATION 2000 Working Group (2005) Seismic and geological structure of the crust in the transition from Baltica to Palaeozoic Europe in SE Poland-CELEBRATION 2000 experiment, profile CEL02. Tectonophysics 401:55-77

Mazur S, Mikolajczak M, Krzywiec P, Malinowski M, Buffenmyer V, Lewandowski M (2015) Is the Teisseyre-Tornquist Zone an ancient plate boundary of Baltica? Tectonics 34:2465-2477. https ://doi.org/10.1002/2015TC003934

Narkiewicz M, Grad M, Guterch A, Janik T (2011) Crustal seismic velocity structure of southern Poland: preserved memory of a pre-Devonian terrane accretion at the East European Platform margin. Geol Mag 148:191-210. https://doi.org/10.1017/S0016 $75681000049 X$

Pożaryski W, Dembowski Z (1983) Mapa geologiczna Polski i krajów ościennych bez utworów kenozoicznych, mezozoicznych i permskich, 1:1 000 000. Polish Geological Institute, Warsaw (in Polish)

Puziewicz J (2006) Lower crust and uppermost mantle rocks in the area of the Polonaise'97 seismic experiment-petrologic-seismic models. Prace Państw Inst Geol 188:53-68 (in Polish with English summary)

Puziewicz J, Polkowski M, Grad M (2017) Geophysical and petrological modeling of the lower crust and uppermost mantle in the Variscan and Proterozoic surroundings of the Trans-European Suture Zone in Central Europe. Lithos 276:3-14

Sethian JA (1996) A fast marching level set method for monotonically advancing fronts. Proc Natl Acad Sci USA 93(4):1591-1595
Sethian JA, Popovici AM (1999) 3-D traveltime computation using the fast marching method. Geophysics 64(2):516-523

Skridlaitė G, Bogdanova S, Page L (2006) Mesoproterozoic events in eastern and central Lithuania as recorded by $40 \mathrm{Ar} / 39 \mathrm{Ar}$ ages. Baltica 19:91-98

Środa P, POLONAISE Working Group (1999) P and S wave velocity model of the southwestern margin of the Precambrian East European Craton, POLONAISE'97, profile P3. Tectonophysics 314(1-3):175-192

Środa P, Czuba W, Grad M, Guterch A, Tokarski A, Janik T, Rauch M, Keller GR, Hegedûs E, Vozár J, CELEBRATION 2000 Working Group (2006) Crustal structure of the Western Carpathians from CELEBRATION 2000 profiles CEL01 and CEL04: seismic models and geological implication. Geophys J Int 167:737-760. https ://doi.org/10.1111/j.1365-246X.2006.03104.X

Wessel P, Smith WHF (1995) New version of generic mapping tools released. EOS 76:453

Wiejacz P (1991) Investigation of focal mechanisms of mine tremors by the moment tensor inversion, $\mathrm{Ph}$. D. Thesis. Institute of Geophysics, Polish Academy of Sciences Warsaw (in Polish)

Wilde-Piórko M, Geissler WH, Plomerova J, Grad M, Babuska V, Bruckl E, Cyziene J, Czuba W, England R, Gaczyński E, Gazdova R, Gregersen S, Guterch A, Hanka W, Hegedus E, Heuer B, Jedlicka P, Lazuskiene J, Keller GR, Kind R, Klinge K, Kolinsky P, Komminaho K, Kozlovskaya E, Kruger F, Larsen T, Majdański M, Malek J, Motuza G, Novotny O, Pietrasiak R, Plenefisch Th, Ruzrk B, Sliaupa S, Środa P, Świeczak M, Tiira T, Voss P, Wiejacz P (2008) PASSEQ 2006-2008: Passive seismic experiment in Trans-European Suture Zone. Studia Geophys Geod 52:439-448. https://doi.org/10.1007/s11200-008-0030-2

Wilde-Piórko M, Świeczak M, Grad M, Majdański M (2010) Integrated seismic model of the crust and upper mantle of the Trans-European Suture zone between the Precambrian craton and Phanerozoic terranes in Central Europe. Tectonophysics 481:108-115. https://doi.org/10.1016/j.tecto.2009.05.002

Winchester JA, The PACE TMR Network Team (2002) Palaeozoic amalgamation of Central Europe: new results from recent geological and geophysical investigations. Tectonophysics 360:5-21

Zelt CA (1994) Software package ZPLOT. Bullard Laboratories, University of Cambridge, Cambridge

Zelt CA (1999) Modelling strategies and model assessment for wideangle seismic travel-time data. Geophys J Int 139:183-204

Ziegler PA (1990) Geological atlas of western and central Europe, 2nd ed. Shell International Petroleum Maatschappij, Hague, Geological Society Publishing House, London 